\title{
Matrix metalloproteinase-7 expression in gastric carcinoma
}

\author{
M Honda, M Mori, H Ueo, K Sugimachi, T Akiyoshi
}

\begin{abstract}
Background/Aims-Matrix metalloproteinase-7 (MMP-7) belongs to the same family as matrix degrading metalloproteinase (MMPs) that may play an important part in cancer cell invasion and metastasis. This study reports on the MMP-7 mRNA expression level both in human gastric carcinomas and the normal gastric mucosa.

Methods-From fresh specimens of 47 surgical pairs of primary gastric carcinomas and corresponding normal tissue specimens, cDNA was obtained by reverse transcription (RT) and thereafter MMP-7 mRNAs were detected by means of a polymerase chain reaction. The tumour/ normal (T/N) ratio of $M M P-7$ expression was calculated after correcting for glyceraldehyde-3-phosphate dehydrogenase as an internal control.
\end{abstract}

Results-The expression corrected levels of MMP-7 mRNA of the tumour was greater than that of the normal mucosa in 41 of 47 cases $(87 \%)$. The 13 cases whose $T / N$ ratio was more than $2 \cdot 1$ showed a deeper invasion of the gastric wall, and more frequent lymphatic or vascular permeations than the 34 cases whose $T / N$ ratio was less than $2 \cdot 0$. An immunohistochemical study showed that MMP-7 was predominantly expressed in the cancer cells, weakly expressed in normal epithelial cells, and not expressed in the surrounding stromal cells.

Conclusions-These findings suggest that the overexpression of MMP-7 may thus play an important part in tumour invasion in gastric carcinomas while, in addition, MMP-7 may also prove to be a useful marker for determining the biological aggressiveness of gastric carcinoma. (Gut 1996; 39: 444-448)

Keywords: gastric carcinoma, matrix metalloproteinase-7.

Surary, Oita

Prefectural Hospital, Oita, Japan $\mathrm{H}$ Ueo

Department of Surgery II, Kyushu University, Fukuoka, Japan K Sugimachi

Correspondence to: Dr M Mori,

Department of Surgery, Medical Institute of Bioregulation,

Kyushu University, 4546 Tsurumibaru, Beppu 874, Japan.

Accepted for publication 11 March 1996

or metastasis of surrounding or distant organs. ${ }^{1}$ An initial step of the process may be the degradation of the components of the extracellular matrix and the basement membrane. Many proteolytic enzymes such as metalloproteinases, serine or asparatic proteinases, have been reported to play an essentil part in such matrix degradation. Among the proteolytic enzymes, the matrix metalloproteinases (MMPs) are con- sidered to have an important role in this event. The MMPs have been categorised into three groups consisting of: the collagenases, the stromelysins, and the gelatinases. ${ }^{2} \mathrm{MMP}-7$ is a member of the stromelysin subclass and is the smallest member of the MMP family.

We have used the technique of subtractive complementary DNA (cDNA) cloning to determine potential new markers for human gastrointestinal carcinomas. ${ }^{3-6}$ From a subtracted cDNA library constructed from human gastric cancer tissue minus normal gastric mucosa, we determined one overexpressed clone that showed a $96 \%$ identity with MMP-7. ${ }^{7}$ This thus prompted us to study MMP-7 expression in clinical samples of human gastric carcinoma. MMP-7 has been reported to be overexpressed in several kinds of carcinomas, however, there is still little information on the significance of MMP-7 in human gastric carcinomas. ${ }^{7-11}$ We report on the results of the expression of MMP-7 in human gastric carcinomas and also discuss the significance of its overexpression in patients with gastric carcinoma.

\section{Methods}

\section{Patients and tissue sampling}

The fresh surgical specimens included 47 primary gastric carcinomas and their paired adjacent normal gastric mucosa. Immediately after resection, the necrotic and ulcerated parts of the tumour were removed and the normal gastric mucosa was dissociated from the muscle and connective tissue. All tissue specimens were then frozen in liquid nitrogen and kept at $-90^{\circ} \mathrm{C}$ until the extraction of RNA.

\section{Extraction of total RNA}

The total cellular RNA was extracted from specimens according to the method of Chirgwin et al. ${ }^{12}$ Briefly, each specimen was homogenised in guanidinium isothiocyanate, the total RNA was extracted, and ultracentrifuged through a cesium chloride solution at $32000 \mathrm{rpm}$ for 20 hours. The concentration of RNA was measured using a spectrophotometer (DU-70; Beckman, Fullerton, CA).

\section{$R T-P C R$ and analysis}

A reverse transcriptase-polymerase chain reaction (RT-PCR) was done as follows: oligonucleotide primer pairs for MMP-7 and GAPDH were synthesised on a DNA synthesiser (Applied Biosystems, Foster City, 
CA) (sense MMP-7, 5'-AGATGTGGAGTGCCAGATGT-3'; anti-sense MMP-7, 5'TAGACTGCTACCATCCGTCC-3'10 ${ }^{13}$; sense GAPDH，5'-GTCAACGGDTTTGGFCGTATT-3'; anti-sense GAPDH, 5'-AGTCTTCTGGGTGGCAGTGAT-3'14). The oligonucleotide primer was end labelled with ${ }^{32} \mathrm{P}$-adenosine 5'-triphosphates (Amersham, Tokyo, Japan) at $3000 \mathrm{Ci} / \mathrm{mmol}$ using T4 polynucleotide kinase (New England Biolabs, Beverly, MA), followed by the removal of unincorporated ${ }^{32} \mathrm{P}$ using a spin column. A polymerase chain reaction was carried out in a $25 \mu$ l volume containing $20-30 \mathrm{ng}$ of $\mathrm{cDNA}$ template, $10 \mathrm{pmol}$ each of oligodeoxynucleotide primer, $200 \mathrm{mM}$ each of deoxynucleotide triphosphate, $1.5 \mathrm{mM}$ magnesium chloride, $0.01 \%$ gelatin, and $1.5 \mathrm{U}$ of Taq polymerase (Perkin Elmer Cetus, Norwalk, CT). The samples were overlaid with mineral oil and processed through 24 cycles consisting of one minute at $94^{\circ} \mathrm{C}$ (denaturation), two minutes at $57^{\circ} \mathrm{C}$ (annealing), and two minutes at $72^{\circ} \mathrm{C}$ (elongation). The aliquots of the amplified DNA by polymerase chain reaction were mixed with a formamide gel loading buffer and then were electrophoresed on $2 \%$ agarose gels. The gels were dried, and exposed to an imaging plate. The signals were then quantified using a Bio-Image analyser BAS 1000 (Fuji Photo Coop, Tokyo, Japan). The mRNA expression in tumour $(\mathrm{T})$ and normal $(\mathrm{N})$ tissue in each pair was then estimated based on the counts obtained. The tumour-normal ratio of MMP-7 expression ( $\mathrm{T} / \mathrm{N}$ ratio) was calculated after a correction for that of GAPDH expression.

We determined the nucleotide sequence of each PCR product and confirmed that both were identical to the expected fragments of the cDNAs of MMP-7 and GAPDH. A GenBankUPD New sequences library nucleotide database search demonstrated the sequence to be specific for MMP-7. We also confirmed that the normal tissue examined for the DNA sequence did not contain any carcinoma tissue at all by studying a frozen section.

To check for any possible artefacts based on the possible contamination of RNA by

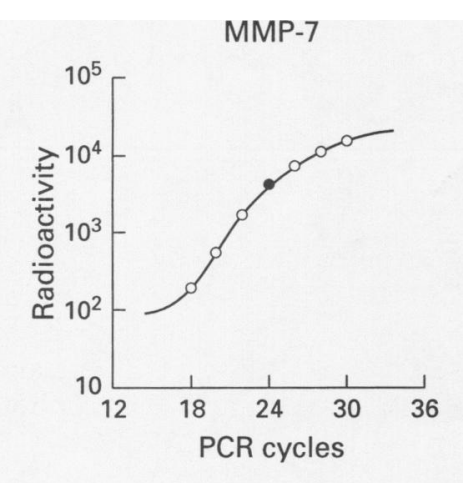

MMP-7

PCR cycles 18202224262830
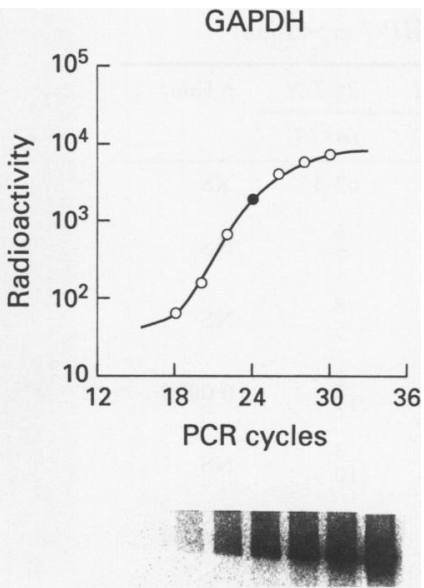

PCR cycles 18202224262830
Figure 1: Correlation between the radioactivity of $P C R$ products and the number of $P C R$ cycles. In both MMP-7 and GAPDH, 24 cycles of PCR are performed according to the conditions mentioned in Methods. genomic DNA during RT-PCR, a few RTPCR reactions were done using a truly positive sample under the same conditions but with no reverse transcription step.

\section{Immunohistochemistry}

To identify the localisation of MMP-7 in the gastric cancer tissue specimens, an immunohistochemical analysis was performed in 10 cases by using a method described previously. ${ }^{5}$ Briefly, five micron thin sections were cut from the AMeX fixed, paraffin wax embedded block. The primary polyclonal antibody used was kindly provided by Professor Miyazaki of the Kihara Institute for Biological Research, Yokohama City University, Japan. The recommended dilution was 1:100. Immunostaining was done by the avidin-biotinperoxidase method.

\section{Clinicopathological findings}

The criteria for pathological diagnosis, such as gross type, depth of tumour invasion, and vascular vessel invasion of the gastric carcinoma tissue, were based on the general rules for gastric cancer outlined by the Japanese Research Society for Gastric Cancer. ${ }^{15}$ The histological type was determined according to Lauren's classification. ${ }^{16}$

\section{Statistical methods}

The associations between the variables were tested by Fisher's exact probability test.

\section{Results}

To approve the quantitative analysis for MMP-7 expression using our RT-PCR method, the values of the radioactivity of the specific band for either MMP-7 or GAPDH were examined based on the various numbers of PCR cycles. Figure 1 shows the values of radioactivity increased linearly at the point of 24 cycles, and thus indicated the quantitative assessment in this assay. The present analysis showed that gastric carcinoma and normal mucosa showed variable levels of MMP-7 mRNA signal. The $T / N$ ratio of $M M P-7$ mRNA, which was corrected for that of GAPDH mRNA, ranged from 0.6 to 3.0 , and was less than 1.0 in six cases (13\%). In $87 \%$ of the cases, the expression of MMP-7 mRNA was greater in $T$ than in $N$. Figure 2 shows representative cases whose $\mathrm{T} / \mathrm{N}$ ratio ranged from 0.85 to 2.92 .

When used in practical evaluations, it is desirable to establish the cut off value of the $\mathrm{T} / \mathrm{N}$ ratio to determine the malignant potentiality in each case. We therefore tried several cut off values to select the best one. In fact we tried $\mathrm{T} / \mathrm{N}$ ratios of $1 \cdot 3,1 \cdot 6,2 \cdot 0$, and $2 \cdot 5$. The mean value of $\mathrm{T} / \mathrm{N}$ ratio of all 47 cases was $1 \cdot 6$. For $1 \cdot 3$ or $1 \cdot 6$, no significant differences in the known prognostic factors between the low $\mathrm{T} / \mathrm{N}$ group and the high $\mathrm{T} / \mathrm{N}$ group were seen. With $2 \cdot 5$, several pathological factors showed a significant difference between 


\section{\begin{tabular}{llllll}
1 & 5 & 3 & 4 & 5 & 6 \\
\hdashline & $\square$ & $\square$ & $\square$ & $\square$
\end{tabular}

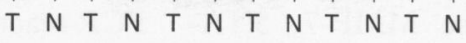 \\ MMP-7

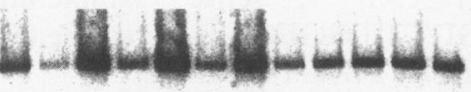 \\ GAPDH

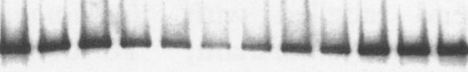 \\ $\begin{array}{lllllll}\mathrm{T} / \mathrm{N} \text { ratio } & 1.51 & 2.71 & 2.11 & 2.92 & 0.98 & 0.85\end{array}$ \\ Figure 2: MMP-7 $m R N A$ expression is seen in six representative cases of gastric carcinoma detected by $R T-P C R . T=$ tumour tissue and $N=$ normal tissue. $G A P D H$ is used as an internal control. The T/N ratio of $M M P-7 m R N A$ corrected for that of GAPDH $m R N A$ is $1 \cdot 51,2 \cdot 71,2 \cdot 92,0.98$, and 0.85 in cases $1,2,3,4,5$, and 6 , respectively.}

the low and the high group, however, the high group number was small $(n=8)$. With $2 \cdot 0$, the high group (group I) number was 13 while the low group (group II) was 34, and several factors showing significant differences between the two were seen. We thus selected 2.0 as the cut off value of $\mathrm{T} / \mathrm{N}$ ratio. As the Table shows group I cases showed a significantly deeper invasion of cancer cells $(p<0.01)$, and higher frequency of lymphatic or vascular vessel permeation $(p<0.05, p<0.01$, respectively) than those in group II cases (Table). Although no significant differences were seen, group I cases tended to metastasise to the lymph nodes more frequently and showed a higher stage of disease than the group II cases. On the other hand, there were no significant differences regarding age, sex, tumour location, tumour size, on histological type of the tumours between groups I and II.

An immunohistochemical study was performed on 10 cases. In the normal mucosal tissue, positive staining was seen in the antral gland epithelium and was very weakly seen in the foveolar epithelium (Fig 3A). In tumour tissue, positive staining was strongly seen in carcinoma cells in all 10 cases (Fig 3B). The stromal mesenchymal cells stained negatively in most areas or very weakly positive in some area.

Clinicopathological data and MMP-7 expression

\begin{tabular}{|c|c|c|c|}
\hline \multirow[t]{2}{*}{ Variables } & $T / N<2$ & $2 \leqq T / N$ & \multirow[t]{2}{*}{$p$ Value } \\
\hline & $(n=34)$ & $(n=13)$ & \\
\hline Age (mean, age) & $68 \cdot 1$ & $63 \cdot 3$ & NS \\
\hline Sex & & & \\
\hline $\begin{array}{l}\text { male } \\
\text { female }\end{array}$ & $\begin{array}{r}25 \\
9\end{array}$ & $\begin{array}{l}6 \\
7\end{array}$ & NS \\
\hline Histology & & & \\
\hline $\begin{array}{l}\text { intestinal } \\
\text { diffuse }\end{array}$ & $\begin{array}{l}16 \\
18\end{array}$ & $\begin{array}{l}8 \\
5\end{array}$ & NS \\
\hline $\begin{array}{l}\text { Depth of invasion } \\
\text { within the wall }\end{array}$ & & & \\
\hline $\begin{array}{l}\text { witnin the wall } \\
\text { bymond the wall } \\
\text { Lymph node metastasis }\end{array}$ & $\begin{array}{l}20 \\
14\end{array}$ & 11 & 0.0098 \\
\hline $\begin{array}{l}\text { absent } \\
\text { present }\end{array}$ & $\begin{array}{l}17 \\
17\end{array}$ & $\begin{array}{r}3 \\
10\end{array}$ & NS \\
\hline $\begin{array}{l}\text { Lymphatic invasion } \\
\text { absent } \\
\text { present }\end{array}$ & $\begin{array}{l}12 \\
22\end{array}$ & $\begin{array}{r}0 \\
13\end{array}$ & 0.0209 \\
\hline $\begin{array}{l}\text { Vascular vessel invasion } \\
\text { absent } \\
\text { present }\end{array}$ & $\begin{array}{l}24 \\
10\end{array}$ & $\begin{array}{r}0 \\
13\end{array}$ & 0.0001 \\
\hline $\begin{array}{l}\text { Stage of disease } \\
\quad 1,2 \\
3,4\end{array}$ & $\begin{array}{l}19 \\
15\end{array}$ & $\begin{array}{r}3 \\
10^{2}\end{array}$ & $\begin{array}{l}\text { NS } \\
(0.0561)\end{array}$ \\
\hline
\end{tabular}

\section{Discussion}

MMP-7 has a wide range of substrates such as gelatin, proteoglycans, fibronectin, elastin, and casein. ${ }^{17} 18$ Its expression is reported to be regulated by oncogenes, growth factors, or hormones. ${ }^{2}$ MMP-7 is structurally different from the other MMPs: it shares a common domain structure such as $\mathrm{N}$-terminal and zinc binding catalytic domain required for proteolytic activity but lacks a conserved carboxylterminal protein domain. ${ }^{11}$ Another different feature of MMP-7 is that it is expressed almost exclusively by malignant or normal epithelial cells. The other MMPs except for MMP-7 and membrane-type $M M P,{ }^{18}$ are expressed by the stromal components of the tissue. ${ }^{19} 20$

MMPs, including MMP-7, have been shown to be overexpressed in several kinds of carcinomas, and to be associated with tumour invasion, metastasis or progression. ${ }^{21}$ The activity of MMPs are regulated by tissue inhibitors of metalloproteinases (TIMP). ${ }^{22}{ }^{23}$ Several experimental studies using TIMP showed that an inhibition of metastasis could be achieved by specific inhibitors of the $M M P s,{ }^{23-26}$ thereby supporting the important part that MMPs play in tumour invasion or metastasis. There have been, however, few experiments that have directly determined the contribution of an individual MMP. With respect to MMP-7, Powell et al reported that a human prostate cancer cell line (DU-145), when transfected with MMP-7 cDNA, gained dramatic invasive potential into the diaphragm after an intraperitoneal injection into SCID mice. ${ }^{8}$ Witty et al also observed differences in invasive potential between MMP-7-transfected human colon cancer cells and control cells when they were injected into mice. ${ }^{27}$ They also

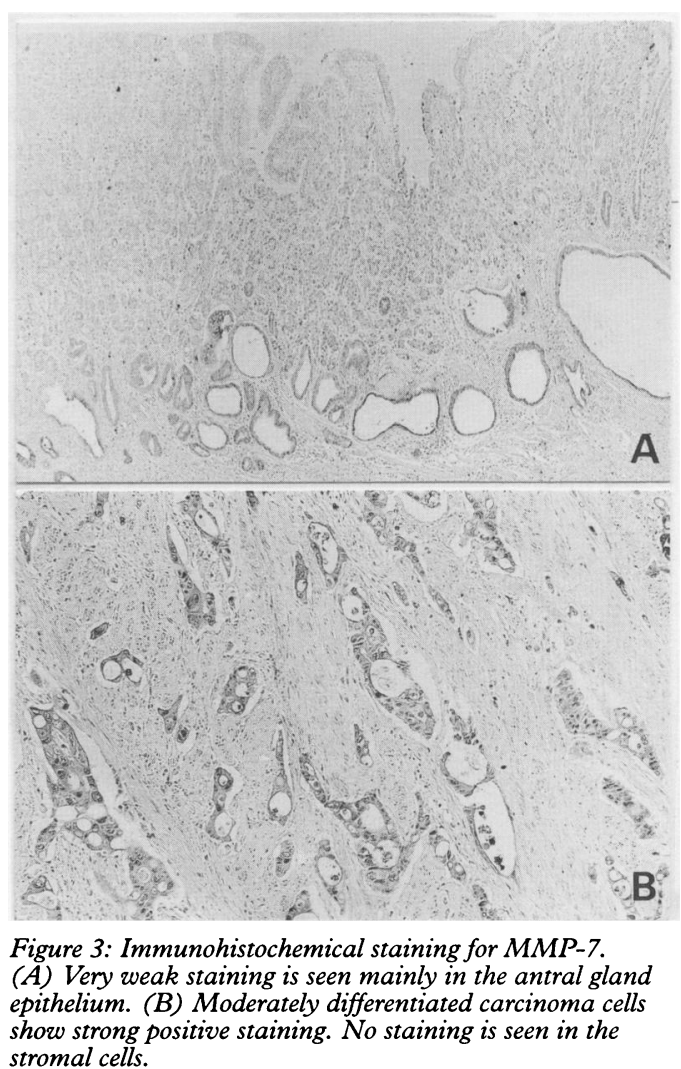


emphasised the significant contribution of MMP-7 to the tumorigenicity and progression of colorectal tumours in vitro.

There have been few reports studying MMP-7 expression in clinical samples. McDonnel et al reported that MMP-7 was overexpressed in six of eight colon carcinomas and in eight of 10 gastric carcinomas by means of a northern blot analysis. They described that there was some correlation between MMP-7 expression and lymph node metastasis, although it was not significant. ${ }^{9}$ Yoshimoto et al studied the expression of MMP-7 in 10 cases of colon carcinoma by means of RT-PCR; nine of 10 cases overexpressed MMP-7 gene, but no detailed clinicopathological analysis was reported. ${ }^{10} \mathrm{We}$ previously studied 47 cases of colorectal carcinoma by means of a northern blot analysis and found that MMP-7 was overexpressed in 39 of 47 tumours compared with their normal counterparts. The expression of MMP-7 mRNA in colorectal tumour tissue increased with increasing Dukes's stage. ${ }^{7}$ Newell et $a l^{28}$ and Yamamoto et $a l^{29}$ reported that the MMP-7 gene was recognised in colon adenomas, which thus suggested that MMP-7 might play a part in the early events of colon tumour progression.

This study showed that MMP-7 expression in gastric carcinoma tissue was greater than that in the normal mucosal tissue of the stomach in $41(87 \%)$ of 48 cases. In addition, the overexpression of MMP-7 in carcinoma tissue correlated significantly with a deeper invasion of the gastric wall, and more frequent lymphatic or vascular vessel permeations. The findings strongly support the hypothesis that MMP-7 expression plays an important part in tumour invasion. The cases with lymph node metastasis were more frequently seen in group I with a high $\mathrm{T} / \mathrm{N}$ ratio of $\mathrm{MMP}-7$ expression than in group II with a low $\mathrm{T} / \mathrm{N}$ ratio, however, the difference was not significant. As the method of RT-PCR used in this study can be done using biopsy specimens, ${ }^{30}$ the determination of the MMP-7 mRNA expression can be done preoperatively and objectively. Therefore, it will provide useful information that will help in determining whether to use chemotherapy or not. In addition, it will also help surgeons to determine what level of lymph node dissection should be done.

MMP-7 expression has been reported to be localised to tumour cells not in stromal cells as mentioned above. Its expression has been seen not only in tumour cells but also in normal epithelial cells of the head and neck, breast, or prostate. ${ }^{31-33}$ Its expression has also been detected in such tissues as the glomerular mesangium, normal kidney cells, or the endometrial epithelium..$^{20}{ }^{34} \mathrm{McD}$ onnell et al showed that MMP-7 mRNA was not detectable by a northern blot in any of the 10 normal tissue samples of the stomach. ${ }^{9}$ Our study, however, disclosed that RT-PCR showed MMP-7 mRNA in the normal gastric mucosa of all 47 cases. We confirmed that the amplified DNA product from normal mucosal tissue and that from carcinoma tissue were both identical to the MMP-7 gene. In addition, the normal tissue did not contain any malignant tissue histologically. To exclude the possibility of contaminating the genomic DNAs, we did the RT-PCR with the omission of the RT enzyme and confirmed there was no amplified DNA product, which thus suggested that there was no contamination of the genomic DNA. The polyclonal antibody for MMP-7 certainly reacted with the normal epithelium of the gastric glands. We therefore consider that MMP-7 was expressed not only in gastric carcinoma cells but also in the normal gastric epithelium, although the expression was weak in the normal epithelium. In conclusion, the overexpression of MMP-7 was recognised in most gastric carcinomas and may therefore contribute to tumour invasion in human gastric carcinomas.

1 Liotta LA, Steeg PS, Stetler-Stevenson WG. Cancer metastasis and angiogenesis: an imbalance of positive and negative regulation. Cell 1991; 64: 327-36.

2 Matrisian LM. The matrix-degrading metalloproteinases. Bioessays 1992; 14: 455-63.

3 Barnard GF, Staniunas RJ, Ba S, Mafune K, Steele GD Jr, Gollan JL, et al. Increased expression of human ribosomal phosphoprotein P0 messenger RNA in hepatocellular carcinoma and colon carcinoma. Cancer Res 1992; 52: carcinom

4 Barnard GF, Staniunas RI, Mori M, Puder M, Jessup JM, Steele GD, et al. Gastric and hepatocellular carcinomas do not overexpress the same ribosomal protein messenger do not overexpress the same ribosomal protein messenger RNAs as

5 Mori M, Barnard GF, Staniunas RJ, Jessup JM, Steele GD, Chen LB. Prothymosin-a mRNA expression correlates with that of cy-myc in human colon cancer. Oncogene 1993; 8: 2821-6.

6 Mori M, Staniunas RJ, Barnard GF, Jessup JM, Steele GD Jr, Chen LB. The significance of carbonic anhydrase expression in human colorectal cancer. Gastroenterology 1993; 105: 820-6.

7 Mori M, Barnard GF, Mimori K, Ueo H, Akiyoshi T, Sugimachi $\mathrm{K}$. Overexpression of Matrix metalloSugimachi $\mathrm{K}$. Overexpression of Matrix metallo-
proteinase $7 \mathrm{mRNA}$ in human colon carcinomas. Cancer proteinase 7 mRNA

8 Powell WC, Knox JD, Navre M, Grogan TM, Kittelson J, Nagle RB, et al. Expression of the metalloproteinase matrilysin in DU-145 cells increases their invasive potential to severe combined immunodeficient mice. Cancer Res 1993; 53: 417-22.

9 McDonnell S, Navre M, Coffey RJ Jr, Matrisian LM. Expression and localization of the matrix metalloproteinase pump-1 (MMP-7) in human gastric and colon carcinomas. Mol Carcinog 1991; 4: 527-33.

10 Yoshimoto $M$, Itoh $F$, Yamamoto $H$, Hinoda $Y$, Ima $K$, Yachi A. Expression of MMP-7 (PUMP-1) mRNA in human colorectal cancers. Int $\mathcal{F}$ Cancer 1993; 54: 614-8.

11 Gaire M, Magbanua Z, McDonnell S, McNeil L, Lovett DH, Matrisian LM. Structure and expression of the human gene for the matrix metalloproteinase the human gene for the matrix metal

12 Chirgwin JM, Przybyla AE, MacDonald RJ, Rutter WJ. Isolation of biologically active ribonucleic acid from sources enriched in ribonuclease. Biochemistry 1979; 18: 5394-9.

13 Muller D, Quantin B, Gesnel MC, Millon-Collard R, Abecassis J, Breathnach R. The collagenase gene family in human consists of at least four members. Biochem 7 1988; 253: 187-92.

14 Tokunaga $H$, Nakamura Y, Sakata K, Fujimori K, Okubo M, Sawada K, et al. Enhanced expression of a glyceraldehyde-3-phosphate dehydrogenase gene in glyceraldehyde-3-phosphate dehydrogenase gene
humans lung cancers. Cancer Res $1987 ; 47: 5616-9$.

15 Japanese Research Society for Gastric Cancer: The general rules for gastric cancer study in surgery and pathology. fpn Surg 1981; 11: 127-39.

16 Mori M, Sakaguchi H, Akazawa K, Tsuneyoshi M, Sueishi K, Sugimachi K. Correlation between metastatic site, histological type, and serum tumor markers of gastric carcinoma. Human Pathol 1995; 26: 504-8.

17 Miyazaki K, Hattori Y, Umenishi F, Yasumitsu H Umeda $M$. Purification and characterization of extracellular matrix-degrading metalloproteinase, matrin (Pump-1), secreted from human rectal carcinoma cell line.Cancer Res 1990; 50: 7758-64.

18 Quantin B, Murphy G, Breathnach R. Pump-1 cDNA codes for a protein with characteristics similar to those of classical collagenase family members. Biochem $\mathcal{f} 1989 ; 28$ : 5327-33.

19 Sato H, Takino T, Okada Y, Cao J, Shinagawa A, Yamamoto E, et al. A matrix metalloproteinase expressed on the surface of invasive tumor cells. Nature 1994; 370: $61-5$. 
20 Rodgers WH, Osteen KG, Matrisian LM, Giudice LC, Gorstein F. Expression and localization of matrilysin, a matrix metalloproteinase, in human endometrium during the reproductive cycle. Am $\mathcal{f}$ Obstet Gynecol 1993; 260: the reproduct

21 Stilter-Stevenson WG, Liotta LA, Kleiner DE Jr. Extracellutar matnix $6:$ role of matrix mein tumor invasion and metastasis. FASEB $\mathcal{f}$ 1993; 7: 1434-41.

22 Albini A, Melchiori A, Santi L, Liotta LA, Brown PD, Stetler-Stevenson WG. Tumor cell invasion inhibited by TIMP-2. ₹ Natl Cancer Inst 1994; 83: 775-9.

23 Tsuchiya Y, Sato H, Endo Y, Okada Y, Mai M, Sasaki T, et al. Tissue inhibitor of metalloproteinase 1 is a negative regulator of the metastatic ability of a human gastric cancer cell line, KKLS, in the chick embryo. Cancer Res 1993; 53: 1397-402.

24 Schultz RM, Siberuman S, Persky B, Bajkowski AS, Carmichael DF. Inhibition by human recombinant tissue inhibitor of metalloproteinases of human amnion invasion and lung colonization by murine B16-F10 melanoma cells. Cancer Res 1988; 48: 5539-45.

25 Alvarez OA, Carmichael DF, DeClerck YA. Inhibition of collagenkytic activity and metastasis of tumor cells by a recombinant human tissue inhibitor of metalloproteinases. I Natl Cancer Inst 1990; 82: 589-95.

26 DeClerek YA, Perez N, Shimada H, Boone TC, Langley KE, Taylor SM Inhibition of invasion and metastasis in cells transfected with an inhibitor of metalloproteinases. Cancer Res 1992; 52: 701-8.

27 Witty JP, McDonnell S, Newell KJ, Cannon P, Navre M, Tressler RJ, et al. Modulation of matrilysin levels in colon carcinoma cell lines affects tumorigenicity in vivo. Cancer Res 1994; 54: 4805-12.
28 Newell K, Witty L, Rodgers WH, Matrisian LM. Expression and localization of matrix-degrading metalloproteinases during colorectal tumorigenesis. Mol Carcinog 1994; 10: during color

29 Yamamoto H, Itoh F, Hinoda Y, Senota A, Yoshimoto M, Nakamura $\mathrm{H}$, et al. Expression of matrilysin mRNA colorectal adenomas and its induction by truncated fibronectin. Biochem Biophys Res Commun 1994; 201: 657-64.

30 Mimori $K$, Mori $M$, Inoue $H$, Ueo $H$, Mafune $K$, Akiyoshi T, Sugimachi $\mathrm{K}$. Elongation factor 1 \% mRNA expression in oesophasgeal carcinoma. Gut 1996; 38: 66-70.

31 Muller D, Breathach R, Engelmann A, Millon R, Bronner $\mathrm{G}$, Flesch $\mathrm{H}$, et al. Expression collagenaserelated metalloproteinase genes in human lung or head and neck tumors. Int 7 Cancer 1991; 48: 550-6.

32 Basset P, Bellocq JP, Wolf C, Stoll I, Hutin P, Limacher JM, et al. A novel metalloproteinase gene specifically
expressed in stromal cells of breast carcinomas. Nature 1990; 348: 699-704.

33 Pajouh MS, Nagle RB, Breathnach R, Finch JS, Brawer MK, Bowden GT. Expression of metalloproteinase genes in human prostate cancer. $f$ Cancer Res Clin Oncol 1991; 117: 144-50.

34 Marti H-P, McNeil L, Thomas G, Davies M, Lovett DH. Molecular characterization of a low-molecular-mass matrix metalloproteinase secreted by glomerular mesangial cells as PUMP-1. Biochem $f$ 1992; 285: 899-905.

35 Pepper MS, Montesano R, Orci L, Vassalli J-D. Plasminogen activator inhibitor- 1 is induced by a chondrocy TE-derived transforming growth factor-beta. Biochem Biophys Res Commun 1991; 176: 633-8. 